\title{
ANALISA PENGENDALIAN KUALITAS DAN PROSES PRODUKSI TERHADAP HARGA POKOK PRODUKSI PADA PT. WAHANA SURYA PLASTIK SURABAYA
}

\author{
*(Sabilar Rosyad ${ }^{1,}$ Muhammad Musyafaq ${ }^{2}$ \\ Prodi Manajemen, Fakultas Ekonomi, Universitas Islam Lamongan \\ Jl. Veteran No.53A Lamongan \\ Telp. ( 0322 ) 324706, Faks. ( 0322 ) 324706 \\ Email:jpim@unisla.ac.id
}

\section{ABSTRAK}

Menghadapi perkembangan dunia industri dan teknologi yang semakin maju, berbagai usaha di lakukan oleh pengusaha untuk mempertahankan kelangsungan hidup, menjaga nama baik (reputasi) perusahaan serta mengantisipasi tujuan jangka pendek dan panjang dan dapat mewujudkan dalam berbagai bentuk kegiatan.salah satu yang di anggap penting yaitu melakukan pengendalian kualitas dan menjaga mutu kualitas atau produk yang di hasilkan. Dengan demikian pada dasarnya pengendalian kualitas bertujuan untuk memastikan bahwa produk yang di hasilkan benar - benar mencapai standar mutu kualitas yang telah di tetapkan sesuai dengan kebutuhan konsumen.

Masalah yang hendak dicari jawabannya adalah : Apakah factor pengendalian kualitas dan proses produksi berpengaruh secara parsial terhadap harga pokok produksi PT. Wahana Surya Plastik Surabaya, Apakah factor pengendalian kualitasdan proses produksi berpengaruh secara simultan terhadap harga pokok produksi PT. Wahana Surya Plastik Surabaya, Variabel manakah yang paling dominan pengaruhnya antara pengendalian kualitas dan proses produksi terhadap hargapokok produksi PT. Wahana Surya PlastikSurabaya.

Sejalan dengan rumusan masalah dan hipotesis tersebut maka penelitian ini menggunakan analisis uji validitas, uji reliabilitas, regresi berganda, korelasi berganda, uji t, koefesien determinansi dan uji simultan menggunakan uji $F$.

Analisis regresi berganda diperoleh persamaan regresi $Y=4,098+0,320 X 1+0,344 X 2$ menunjukan bahwa ada hubungan antara kualitas dan proses produksi terhadap harga pokok produksi di PT. Wahana Surya Plastik Surabaya.Dari hasil analisis pengolahan data antara Variabel kualitas dan proses produksi terhadap harga pokok produksi di PT. Wahana Surya Plastik Surabaya besarnya nilai $R=0,487$. Artinya korelasi variabel kualitas dan proses produksi terhadap harga pokok produksi di PT. Wahana Surya Plastik Surabaya mempunyai hubungan yang sedang dan postif karna nilainya diantara 0,40-0,60.Dari hasil penghitungan 
diatas menunjukan bahwa thitung 3,046 > ttabel 1,671 sehingga dari keadaan tersebut dapat ditarik kesimpulan bahwa Ho ditolak dan Ha diterima yang berarti bahwa variabel kualitas (X1) mempengaruhi harga pokok produksi di PT. Wahana Surya Plastik Surabaya dan thitung 1,680 > ttabel 1,671 sehingga dari keadaan tersebut dapat ditarik kesimpulan bahwa Ho ditolak dan Ha diterima yang berarti bahwa variabel proses produksi (X2) mempengaruhi harga pokok produksi di PT. Wahana Surya Plastik Surabaya.Dari hasil uji F menunujkan bahwa variabel kualitas (X1) dan proses produksi (X2) berpengaruh secara simultan terhadap harga pokok produksi di PT. Wahana Surya Plastik Surabaya hal itu dapat dilihat dari hasil analisa yang menunjukan Fhitung > dari Ftabel atau 7,32 > 3,19.

Kata kunci : pengendalian kualitas, proses produksi dan HPP

\section{Latar Belakang}

Menghadapi perkembangan dunia industri dan teknologi yang semakin maju,berbagai usaha di lakukan oleh pengusaha untuk mempertahankan kelangsungan hidup, menjga nama baik (reputasi) perusahaan serta mengantisipasi tujuan jangka pendek dan panjang dan dapat mewujudkan dalam berbagai bentuk kegiatan.salah satu yang di anggap penting yaitu melakukan pengendalian kualitas dan menjaga mutu kualitas atau produk yang di hasilkan. Dengan demikian pada dasarnya pengendalian kualitas bertujuan untuk memastikan bahwa produk yang di hasilkan benar-benar mencapai standar mutu kualitas yang telah di tetapkan sesuai dengan kebutuhan konsumen.
Disisi lain persaingan antar perusahaan yang semakin ketat menyebabkan perusahaan dituntut untuk meninkatkan mutu atau kualitas produknya serta haraga dan pelyanan yang lebih baik dalam menjangkau konsumen sebanyak-banyaknya, karena karena kualitas produk yang di hasilkan oleh perusahaan dan harga yang baik akan sangat berpengaruh terhadap perusahaan tersebut dalam jangka panjang.

Kualitas produk yang baik dengan proses produksi yang baik dan didukung dengan harga yang tidak terlalu tinggi akan banyak membantu pemasaran produk, sebaliknya apabila kualitas tidak diperhatikan atau selalu berubah dan harga yang tidak sesuai maka konsumen akan akan menjauh atau menghindari produk yang dihasilkan, dengan demikian peusahaan akn mengalami kesulitan pemasaran produk yang di hasilkan 
dalam jangka panjang. Atas pertimbangan dan fakta tersebut di atas maka pembahasan masalah pengendalian kualitas,proses produksi dan harga produk masih dipandang perlu dan relevan.

Berdasarkan uraian - uraian di atas dapat di simpulkan bahwa kegiatan pengendalian kualitas, proses produksi dan harga produk sangat diperlukan dalam melaksanakan suatu pekerjaan agar penyimpangan - penyimpangan yang mungkin timbul dapat di atasi sehingga pekerjaan dapat dilakukan sesuai rencana, oleh karena itu pengendalian kualitas, proses produksi dan harga produk mendapat perhatian khusus karena sangat menentukan keberhasilan perusahaan un tuk mencapai tujuannya.

\section{Landasan teori}

\section{a. Pengertian Pengendalian}

Pada setiap tahap kegiatan perlu perlu dilakukan pengendalian. Sebab apabila terjadi penyimpangan akan lebih cepat diadakan tindakan koreksi. Menurut Sumarni dan Soeprihanto ( 2005 : 142 ), dalam bukunya.Pengendalian adalah aktivitas untuk menemukan, mengoreksi adanya penyimpangan-penyimpangan dari hasil yang telah di capai dibandingkan dengan rencana kerja yang telah ditetapkan.

Dari devinisi di atas dapat disimpulkan bahwa funsi pengendalian adalah fungsi terakhir dari manajemen yang harus dilaksanakan oleh manajer.Cara-cara pengendalian kualitas yang baik (Sumarni dan Soeprihanto 2005 :143 ) :

1) Pengendalian harus mendukung sifat atau kebutuhan dari kegiatan untuk masingmasing kegiatan.

2) Pengendalian harus berorientasi jauh ke depan untuk mengetahui yang akan datang maka manajemen perlu membuat perkiraan situasi yang mungkin terjadi.

3) Pengendalian harus akurat dan obyektif

4) Pengendalian harus fleksibel,di dalam melksanakan pengendalian perlu dicari alternatif-alternatif rencana untuk situasi yang memungkinkan.

5) Pengendalian harus ekonomis karena pengendalian adalah alat untuk mencapai tujuan, sehingga biaya-biaya pengendalian perlu diusahakan agar seminimal mungkin.

6) Pengendalian harus mudah dimengerti,cara-cara pengendalian harus disesuaikan dengan tingkat pengetahuan yang dimiliki oleh pelaksana pengendalian itu.

7) Pengendalian harus diikuti dengan tindakan koreksi, cara pengendalian yang baik harus dapat menunjukan letak penyimpangan yang terjadi.

pengendalian tidak hanya dilakukan bagi para pekerja di perusahaan, namun mencakup semua bidang dalam 
perusahaan.secara singkat pengendalian dapat dilakukanpada bidang:

1) Produksi

Dibidang ini pengendalian dimulai saat menerima pesanan dari pembeli kemudian melakukan pembelian bahan sampai produk selesai dibuat.

2) Pemasaran

Pengendalian pemasaran mulai terasa saat produk dikirim ke pasar / konsumen.

3) Keuangan

Bidang keuangan harus ditangani dengan cepat dan tepat, pengendalian keuangan yang kurang teliti akan berakibat perusahan terjerumus di dalam kesulitan keuangan. Jika pengendalian keuangan baik maka perusahaan baik dalam keuangan.

\section{b. Pengertian Kualitas}

Kualitas ditinjau dari subyektif adalah sesuatu yang cocok untuk digunakan (fitness for use) jadi suatu produk bisa dikatakan berkualitas apabila produk tersebut mempunyai kecocokan penggunaan bagi dirinya.

Beberapa pakar memberikan pengertian tentang kualitas secara berbeda-beda menurut sudut pandangnya masing-masing.

American society for quality control dalam kotler (1997 : 49) mendefinisikan kualitas sebagai keseluruhan ciri serta sifat dari suatu produk atau pelayanan yang berpengaruh pada kemampuannya untuk memuaskan kebutuhan yang dinyatakan atau tersirat". Kita dapat menyatakan bahwa perusahaan telah menghasilkan kualitas apabila produk atau pelayanan mereka memenuhi atau melebihi harapan pembeli (konsumen).

Menurut Sukanto Reksohadiprojo (2003 : 465) kualitas adalah Ukuran seberapa dekat suatu barang atau jasa sesuai dengan standar tertentu. Standar mungkin bertalian dengan waktu, bahan, kinerja, kehandalan atau karakteristik (obyektif dan dapat di ukur) yang dapat di kuantifikasikan.

Pendapat lain dari salah satu pakar kualitas yang dikutip oleh uselac dalam tipono (2003 : 3) menegaskan bahwa "kualitas bukan hanya mencakup produksi dan jasa tetapi juga meliputi proses, lingkungan, dan manusia. Bahkan ditegaskan pula direktur G. E John F. Welch, Jr yang dikuttip oleh kotler (1997 : 48) bahwa "kualitas merupakan jaminan terbaik atas kesiapan pelanggan, pertahanan terkuat kita dalam menghadapi pesaing dan satusatunya menuju pertumbuhan dan pendapatan yang langgeng".

Berdasar uraian di atas maka, dapat diperoleh kesimpulan bahwa kualitas merupakan factor yang terdapat pada suatu barang atau hasil tersebut sesuai dengan tujuan untuk apa barang atau hasil itu dibutuhkan. Dan, sifat (kualitas) 
tersebut tergantung dari produk yang dihasilkan, tetapi yang penting adalah produk tersebut bisa memuaskan konsumen dalam hal kualitasnya yaitu baik sifat produk itu sendiri seperti warna, susunan, kekuatan dan sebagainya.

\section{c. Harga Pokok Produksi}

Menurut Ir. Arman Hakim Nasution, M. Eng. (2006:192) Hargav pokok produksi perlu di hitung dan di tentukan dengan tepat. Bidang ilmu yang membahas tentang penentuan harga pokok produksi adalah akutansi biaya.Meskipun demikian akutansi biaya tidak hanya sekedar menetukan harga pokok produksi saja, tetapi juga menentukan nilai persediaan, memelihara biaya serendah mungkin, dan menetukan harga jual dan kebijaksanaan penjualan berdasarkan hasil perhitungan harga pokok poduksi tersebut.Harga adalah sejumlah uang (ditambah beberapa barang kalau mungkin) yang dibutuhkan untuk mendapatkan sejumlah kombinasi dari barang beserta pelayanannya.

\section{Metode analisis data}

a. Uji Analisis Data

1) Uji Releabilitas

Reliabilitas adalah alat untuk mengukur suatu kuesioner yang merupakan indikator dari suatu variabel.Suatu kuesioner dikatakan reliable atau handal jika jawaban pertanyaan adalah konsisten atau stabil dari waktu ke waktu (Ghozali, 2005).

Pengukuran reliabilitas dalam penelitian ini dilakukan dengan cara one shot atau pengukuran sekali saja. Disini pengukuran hanya sekali dan kemudian hasilnya dibandingkan dengan pertanyaan lain atau mengukur reliabilitas dengan uji statistik Cronbach Alpha (a). Suatu variabel dikatakan reliable jika nilai Cronbach Alpha (a) > 0,6.

2) Uji Validitas

Uji validitas digunakan untuk mengukur sah atau valid tidaknya suatu kuesioner. Suatu kuesioner dikatakan valid jika pertanyaan dan kuesioner mampu untuk mengungkap sesuatu yang akan diukur oleh kuesioner tersebut (Ghozali, 2005).

Dalam penelitian ini menggunakan content validity yang dapat menggambarkan kesesuaian sebuah pengukuran data dengan apa yang diukur (Ferdinand, 2006). Jika suatu indikator mempunyai korelasi antara skor masing-masing indikator terhadap skor totalnya (skor variabel konstruk) maka dikatakan indikator tersebut valid.

\section{3). Regresi Berganda}

Menurut Suharsimin arikunto (2010 : 250) analisa regresi berganda digunakan oleh peneliti, bila peneliti bermaksud meramalkan bagamana keadaan variabel dependent. 
Analisa regresi berganda digunakan untuk mengetahui besarnya pengaruh masing-masing variabel bebas terhadap variabel terikat.Analisa ini digunakan bila variabel indipendentnya minimal 2.

\section{3) Korelasi}

Korelasi merupakan alat ukur untuk mengetahui pertautan antara variabel tidak bebas ( variabel Y) dengan variabel bebas (variabel $\mathrm{X}_{1}, \mathrm{X}_{2} \ldots \ldots \mathrm{X}_{\mathrm{k}}$ ) secara serempak. ( Dr. Sudjana, 1996 ).

\section{4) Uji t}

Uji $\mathrm{t}$ digunakan untuk menguji signifikasi / tidaknya hubungan antara variabel bebas dan variabel terikat. Adapun rumus dari uji t adalah (Sugiyono, $2006: 215$ )

\section{5) Koefisien deteminasi}

Koefisien determinasi (R2) pada intinya mengukur seberapa jauh kemampuan sebuah model menerangkan variasi variabel dependen.Nilai koefisien determinasi adalah antara nol dan satu.Nilai R2 yang kecil berarti kemampuan variabel-variabel independen dalam menjelaskan variabel dependen sangat terbatas.Nilai yang mendekati satu berarti variabel-variabel independen memberikan hampir semua informasi yang dibutuhkan untuk memprediksi variasi variabel dependen (Ghozali, 2005).

6) Uji F
Dalam penelitian ini, uji $\mathrm{F}$ digunakan untuk mengetahui tingkat siginifikansi pengaruh variabel-variabel independen secara bersama-sama (simultan) terhadap variabel dependen (Ghozali, 2005:84).

\section{Pembahasan}

\section{UjiKualitasData}

a. UjiValiditas

\section{Uji Validitas}

Validitas adalah suatu ukuran yang digunakan dalam mengukur tingkat kevalidan atau keabsahan suatu instrumen penelitian. Suatu instrumen penelitian yang valid mempengaruhi validitas yang tinggi. Sebaliknya suatu instrumen yang kurang valid akan memiliki validitas rendah.

uji validitas ini merupakan suatu ukuran yang memperlihatkan tingkat kevalidan suatu instrument, dari hasil perhitungan menggunakan SPSS maka didapatkan data sebagai berikut :

Berdasarkan tabel diatas yakni hasil olahan data mengenai uji validitas menunjukan bahawa variabel antrian $\left(\mathrm{X}_{1}\right)$ dengan 3 item pertanyaan kemudian variabel Pelayanan $\left(\mathrm{X}_{2}\right)$, maka dapa disimpulkan bahwa 6 item pertanyaan sudah valid karena memiliki nilai korelasi diatas 0,297.

\section{Uji Reliabilitas}


Reliabilitas menunjukkan sesuatu instrumenyang dapat digunakan sebagai alatpengumpul

data, karena instrumen dapat dipercaya danreliabel yang akan menghasilkan datayangdapat dipercaya. Suatu data instrumen penelitian dikatakan reliabel menurut Ghozali (2006 : 133) apabila memiliki nilai cronbach's alpha $>0,60$.

Adapun hasil olahan data mengenai reliabilitas data instrumen penelitian yaitu sebagai berikut :Berdasarkan tabel 5. yakni hasil pengolahan data mengenai reliabilitas, yang menunjukkan bahwa semua item pernyataan yang diajukan sudah reliabel atau handal, hal ini dapat dilihat dari variabel Kualitas $\left(\mathrm{X}_{1}\right)$ memiliki nilai cronbach's alpha 0,680 , untuk Variabel proses produksi $\left(\mathrm{X}_{2}\right)$ memiliki cronbach's alpha sebesar 1,206, sehingga dapat disimpulkan bahwa semua variabel sudah handal karena memiliki nilai cronbach's alpha diatas dari 0,60

\section{PENUTUP}

\section{a. Kesimpulan}

Berdasarkan hasil penghitungan dan uraian diatas dapat disimpulkan sebagai berikut :

1. Dari hasil yang diperoleh diatas, terdapat hubungan yang positif (+) antara variabel bebas dengan variabel terikat yakni sebesar 0,57 , hal ini berarti bahwa arahnya positif (+) dan kuatnya hubungan sebesar 0,57 , dan tin gkat hubungannya antara variabel $\mathrm{X}$ dengan variabel $\mathrm{Y}$ tergolong sedang karena nilainya antara 0,40-0,599. Dengan demikian apabila kualitas dan proses produksi di naikan, maka akan semakin tinggi pula harga pokok produksi di PT. Wahana Surya Plastik Surabaya.

2. Dari hasil penghitungan menunjukan bahwa $\mathrm{t}_{\text {hitung }} 3,396>\mathrm{t}_{\text {tabel }}$ 2,01 sehingga dari keadaan tersebut dapat ditarik kesimpulan bahwa Ho ditolak dan $\mathrm{Ha}$ diterima yang berarti bahwa variabel Kualitas $\left(\mathrm{X}_{1}\right)$ berpengaruh secara signifikan terhadap harga pokok produksi di PT. Wahana surya plastic surabaya. Dan $t_{\text {hitung }}$ $4,188>t_{\text {tabel }} 2,01$ sehingga dari keadaan tersebut dapat ditarik kesimpulan bahwa Ho ditolak dan Ha diterima yang berarti bahwa variabel proses produksi $\left(\mathrm{X}_{1}\right)$ berpengaruh secara signifikan terhadap harga pokok produski di PT. Wahana surya plastik Surabaya.

3. F tabel yang diperoleh adalah 3,19. Dengan demikian $\mathrm{F}$ hitung $>\mathrm{F}$ tabel $(66,33>3,19)$, maka dapat disimpulakan bahwa Variabel Kualitas (X1) dan proses produksi (X2) berpengaruh positif dan simultan terhadap harga pokok produksi di PT.Wahana Surya Plastik Surabaya.

4. Dari hasil yang diperoleh diatas, terdapat hubungan yang positif (+) antara variabel bebas dengan variabel terikat yakni sebesar 0,57, hal ini berarti bahwa arahnya positif (+) 
dan kuatnya hubungan sebesar 0,57, dan tingkat hubungannya antara variabel $\mathrm{X}$ dengan variabel $Y$ tergolong sedang karena nilainya antara 0,40-0,599. Dengan demikian apabila kualitas dan proses produksi di naikan, maka akan semakin tinggi pula harga pokok produksi di PT. Wahana Surya Plastik Surabaya

5. Dari hasil penghitungan diatas menunjukan bahwa thitung 3,396 > tabel 2,01 sehingga dari keadaan tersebut dapat ditarik kesimpulan bahwa Ho ditolak dan Ha diterima yang berarti bahwa variabel Kualitas (X1) berpengaruh secara signifikan terhadap harga pokok produksi di PT. Wahana surya plastic Surabaya, dan Proses Produksi (X2) thitung 4,188 > ttabel 2,01 sehingga dari keadaan tersebut dapat ditarik kesimpulan bahwa Ho ditolak dan Ha diterima yang berarti bahwa variabel proses produksi (X2) berpengaruh secara signifikan terhadap harga pokok produski di PT. Wahana surya plastik Surabaya

\section{Dengan demikian F hitung > F tabel (} $66,33>3,19)$, maka dapat disimpulakan bahwa Variabel Kualitas (X1) dan proses produksi (X2) berpengaruh positif dan simultan terhadap harga pokok produksi di PT.Wahana Surya Plastik Surabaya.

\section{b. Saran}

Setelah dilakukan penelitian dan menghasilkan suatu kesimpulan, maka penelitimencobauntukmemberikansaran yang kiranya bermanfaat:

1. Perusahaan harus benar-benar teliti dalam memilih bahan baku agar harga pokok produksi bisa terkontrol.

2. Perrusahaan harus mengendalikan proses produksi dengan baik guna meminimalisir harga pokok produksi.

3. Bagi peneliti berikutnya yang tertarik untuk melakukan penelitian dibidang yang sama dapat menggunakan variabel independen yang tidak digunakan dalam penelitian ini, agar diketahui variabel independen yang lain yang berpengaruh terhadap harga pokok produksi, karena kemungkinan masih ada variabel lain yang mempengaruhi harga pokok produksi.

\section{DAFTAR PUSTAKA}

Assauri, Sofyan, 1998. Manajemen operasi

dan produksi, Penenrbit Fakultas

Ekonomi Indonesia.

Tipjono, Fandi, Diana, 2003. Total Quality

Mananjemen, Penenrbit ANDI

Lamongan.

Reksohadiprojo, Sukanto, Mananjemen

produksi, Penerbit BPFE, Yogyakarta.

Sudjana. 1996. Metode statistik, Penenrbit

Tarsito Bandung.

Arikunto, Suharsimi, 2010. Prosedur

Penenlitian, Penenrbit Rineka Cipta

Yogyakarta. 
Sugiono, 2006. Metode Penenlitian

Kuantitatif Dan Kualitatif, Penerbit

CV. Alfabeta bandung.

Kotler, Philip, 2002. Manajemen Pemasaran,

Edisi 10, Penerbit PT. Prenhallindo

Jakarta.

Ahyari, Agus, 1999. Manajemen Produksi,

Edisi IV, Penerbit BPFE, Yogyakarta.

Sumarni, Marti-Soeprihanto, John, 1995.

Pengantar Bisnis ( Dasar-Dasar Ekonomi

Perusahaan ) Edisi keempat, Yogyakarta,

Penerbit Liberty.

Swastha, Basu-Sukotjo, Ibnu, 2002.

Pengantar Bisnis Modern, Penerbit

Liberty, Yogyakarta.

Unisla, 2011. Pedoman Penyusunan Skripsi

Fakultas Ekonomi. Lamongan Unisla. 